\title{
Predicates of Indonesian and English Simple Sentences
}

\author{
Ingatan Gulö \\ atan@teknokrat.ac.id
}

\author{
Universitas Teknokrat Indonesia
}

\begin{abstract}
This paper was developed from a research report presented in The Third Southern Region of Sumatera TEFLIN held by Sriwijaya University in 2014. Comments recieved by the participants of the seminar and following studies done on the topic made it possible for this article to find its way to be published in a journal. As Indonesian and English sentences realize their predicates by using different kinds of syntactic categories, most learners of English having Indonesian as their linguistic background face difficulties in understanding the language. This is a contrastive study done by conducting an analytical analysis on simple sentences of both languages. The result of this research shows that both English and Indonesian sentences employ verbs as their predicates. However, in addition to verbs, Indonesian sentences also use other kinds of syntactic categories such as nouns, adjectives, etc. to be the predicates of sentences. These main differences of English and Indonesian systems have to be underlined in learning process and teaching English to learners in order to avoid grammatical mistakes.
\end{abstract}

Key Words: adjective, adverb, predicate, noun, verb

\section{Introduction}

Borsley defines predicate as the one that says something about whoever or whatever the subject refers to (2003: 85). This means that as a crucial part of a sentence, predicate refers to that which is not the subject of the sentence. Instead, it tells something about the subject. In this study, however, those that function as objects and adverbials are sometimes not counted as parts of predicates. Apart from the implication that the above definition is considering the part from a verb or a verb phrase to the end of an English sentence as a predicate, unless it is specified, the focus here is on the verb or the verb phrase.

While English predicates consist of verbs as the most important constituents (Greenbaum and Nelson, 2002: 21), other languages such as Indonesian and Bataknese, a local language spoken in the western part of Indonesia, may use words in other categories as the predicates (Shopen, 2007: 224). The combination of these predicates with their subjects form the main elements of simple and even complex sentences. A simple sentence is the one that contains only one subject and one predicate. It is also called a major clause in its independent form.

As Greenbaum and Nelson (2002: 16) put it, "A sentence that does not contain another clause within it is a simple sentence." This distinguishes the characteristic of a complex sentence which has more than one subject as well as the predicate. To narrow the analysis, this research focuses on the simple sentences of both languages. Although English and Indonesian sentences are much the same in their typical word order, that is S-V-O, they show differences in the word categories that can take the position of a verb as the predicate. This needs a scientific explanation as to what differences they have and how to anticipate the mistakes might be made as the result of interference from both languages.

\section{Method}

This is a descriptive-analytical qualitative research that makes use of available facts or information to analyze and to make a critical evaluation of (Kothari, 2004: 110; Stake, 2010). The main objects of this synchronic study are Indonesian and English simple sentences. The sources of the data were short stories. English source of data was the short story The Seven Poor Travelers written by Charles Dickens and published by the University of Adelaide in 2013 and the Indonesian source of data was the short story written by M. Fathoni Arief entitled Darah Jawa posted in 2007 on a website.

In collecting the data, both primary and secondary, it was content-analysis method which was applied. Kothari says that this kind of method is concerned with the study of messages in existing documents or verbal materials (2004: 110). Thus, to collect the data necessary for this study, the researcher decided the kinds of source or English and Indonesian texts from which the data would be taken. Then, he read the texts to make sure the data 
available were sufficient for the research. The last step was to re-read the data source of each language, choose the data containing any kinds of predicates, and write them down on papers to be processed.

There were some steps that were be done in analyzing the data. First, complex sentences were omitted. Second, the raw data were examined in order to find errors or omissions during the process of collecting. Third, the data were assigned numerals or certain symbols so that it would be easier to put them into appropriate classifications. Fourth, the researcher sorted the data according to their kinds of predicates. Fifth, the researcher observed how certain kinds of predicates are realized in their simple sentences.

\section{Findings and Discussion}

This part of the article is divided into four points: verbs as predicators, nouns as predicates, adjectives as predicates, and other phrases as predicates. To easily refer to the data, they are number in an order across different points.

\section{Verbs as Predicators}

Both English and Indonesian employ verbs as predicates in sentences. Aarts (2001: 9) and Greenbaum and Nelson (2002: 21) define predicate as everything in the sentence except the subject. Bas Aarts specifies that the verb alone is called predicator (2001: 14-15). This means that the verb phrase or the predicator, the noun phrases that function as direct object and indirect object, as well as the adverbials which might be present in a ditransitive sentence, for instance, are all included in the predicate because they follow the subject. From the examples below, the italicized parts function as the predicates and the underlined ones are the predicators.

(1) The gentlemen $\underline{\text { met. }}$.

(2) I found them.

(3) Aku datang ke sini.

(4) Ia meneteskan air mata.

It is obvious here that the verbs in both English and Indonesian can function as predicators. Sentence (1) is one of English examples for this fact. In Indonesian, sentence (3) can be used as an example because the adverbial $k e$ sini can be omitted, leaving the verb datang alone as the predicator. There is another case from the collected and analysed data that is worth presented here like Mereka semua meninggal 'They all died' in which, like that in (1), one verb acts as the predicate as well as the predicator.

The verbs in (1) and (3) are intransitive and the ones in (2) and (4) are transitive but they all function as predicators with the same position after the subjects. When other kinds of verbs are used in this sentence type, the order and the function hold, like (5) and (6) given below.

(5) The matron gave them their five cents.

(6) Kakek dan nenek memberikan aku sebuah nama.

These ditransitive verbs occupy the same functions as those other kinds do in sentence (1) through (4) above. The other kinds of verbs such as complex transitive and intensive are all subject to this pattern in both English and Indonesian typical declarative sentences. This similarity between English and Indonesian verbs to function as predicate makes it easier to learners, especially English students learning Indonesian, to transfer the English pattern to Indonesian.

Thus, in saying I found them, for example, can be easily put into Saya menemukan mereka without significant issue to comprehend. Doing the same thing from Indonesian to English, however, is not as straight forward as this. It needs other grammatical issue as to what number of the subject it refers to and in what tense the verb should be put. The kind of problem found by Indonesian students in learning English, however, is not as difficult as the ones going to be discussed below. It is because in this case, both Indonesian and English linguistics allow verbs to be predicators or predicates.

\section{Nouns as Predicates}

Not like in English, Indonesian nouns can function as predicates. The following simple sentences have proper noun as in (7), common noun as in (8), and noun phrase as in (9) as their predicates in the sense they say things about the subjects.

(7) Namanya Vrida. 
(8) Itu petunjuk.

(9) Hari ini hari pertama.

This is not the way it works in English. The nouns themselves cannot act as predicates for the subjects. In other words, all English major clauses or simple sentences must have verbs in their predicates. To be, which in its form has to agree with the number of the subject, is needed in order to fill the position of the predicator. As seen from examples (10) and (11), the italicized words are the predicators.

(10) They are French officers.

(11) Next year is the year of the proclamation.

Pattern like this one poses a grammatical difficulty when changing Indonesian sentences into English. It is very often that Indonesian students misunderstand this rule of nominal sentences. The above three Indonesian simple constructions, for instance, may incorrectly be put into translations like in (12 through (14).

(12) *Her name Vrida.

(13) *It a clue.

(14) *Today the first day.

Seen from those ungrammatical constructions, verbs are absent and this causes the sentences to be ill-formed. Students often produce this kind of sentences not only when enganging in a conversation or delivering a presentation but also when writing a paper or other assignments. In order to avoid such grammatical mistakes, it is important to underline that the presence of verbs is essential in forming English sentences. Shopen calls this as nominal predicate (2007: 229).

\section{Adjectives as Predicates}

Just like the nouns, Indonesian adjectives are also used as predicates. In using them, there is no special grammatical rule to be think about. They are used in exactly the same way Indonesian nouns are used as predicates. Simple sentences below portray how adjectives or adjective phrases tell things about the subjects they refer to.

(15) Pelabuhan di bagian Timur ini cukup ramai.

(16) Kedatanganku sia-sia.

(17) Beliau masih begitu muda.

That in (15) employs an adjective phrase cukup ramai which literally means 'crowded enough' to explain the subject Pelabuhan di bagian Timur ini that refers to a place. The adjective phrases in (16) and (17) behave the same. Taking (17) as an example, the phrase's head muda that means 'young' forms a constituent with its modifier masih begitu 'still very' to explain the subject Beliau 's/he'. English adjectives in contrary cannot be grammatically correct when used alone as predicates. In order for this kind of word class becomes the part of a predicate, intensive verb such as to be is needed. This can be seen from the data presented below.

(18) The story is intelligible.

(19) Those faces are familiar.

Seen from the above, the presence of $i s$ and are is necessary in order to form those grammatically acceptable sentences. The comparison between these English simple sentences to those of Indonesian in (15) through (17) shows that the latter cannot be translated as follow.

(20) *The harbor in the East crowded enough.

(21) * My coming useless.

(22)*She still so young.

These grammatical errors, however, always happen when changing Indonesian sentences into English or whenever Indonesian students speak or write in English. The reason behind this is the application of Indonesian grammatical structure to that of English. To have acceptable constructions, appropriate forms of intensive verbs must be inserted after the italicized subjects of those simple sentences.

\section{Other Phrases as Predicates}

The fourth kind of Indonesian linguistic unit that can be employed as predicate is adverb of place such as $d i$ sini or ke pasar in their prepositional forms. This will be illustrated by the simple sentences given here. 
(23) Aku dari daerah sini.

(24) Nenek moyangku ke Suriname ratusan tahun yang lalu.

(25) Mereka di sana.

It is obvious from the italicized phrases that they functions as the predicates of the sentences. The sentences above contain no verbs. That in (23) consists of a personal pronoun $A k u$ 'I' and a prepositional phrase dari daerah sini literally 'from this area'. This phrase functions as the predicate of the subject $I$. The one in (24) employs Nenek moyangku 'My ancestors' as the subject, prepositional phrase ke Suriname as the main predicate, and another phrase ratusan tahun yang lalu as an adverb of time. Like (23), there is no verb in it. The predicate, however, has to be underlined here, can also extend from the prepositional phrase ke Suriname to the end of the sentence, making the adverbial as a part of the predicate. Number (25) is much simpler; a personal pronoun Mereka 'They' and a prepositional phrase di sana 'there'. Like the others, no verb is employed here.

When daerah, Suriname, and sana are seen as independent words, they are actually, respectively, noun, proper noun, and pronoun, but the presence of the prepositions in front of them make them adverbs of place. English adverbs of place alone cannot function as predicates.

(26) *I from this area.

(27) * My ancestors to Suriname hundred years ago.

(28) *They there.

Literally translated from the previous ones, those English simple sentences above, from (26) through (28), are grammatically incorrect. Looking at their word-for-word counterparts in (23) through (25), however, makes it seem logical to have such constructions. Students with lack of understanding of English grammatical rules and lack of practice on producing English sentences may take this for granted. However, this is not the way English pattern works. They need verbs that link those preposition phrases to the subjects as in the sentences below.

(29) They are on the bank of the river.

(30) The trouble is in your mind.

(31) The six travelers were in the room.

Based on this pattern then the incorrect examples above can be put in their grammatically correct forms like I am from this area, My ancestors went to Suriname hundred years ago, and They are here. A lot of English sentences are in this kind of form. It is significant to underline this difference with Indonesian sentences. When teaching English to students with Indonesian linguistic background, thus, a teacher should pay attention to these notions of language diversities.

In addition to adverbials, phrases related to time and number can also function as predicates in Indonesian. Sentences like Mobil mereka tiga and Acaranya jam tujuh, for examples, employ the word tiga 'three' and the phrase jam tujuh 'seven o'clock' which are related to number and time as the predicates. These sentences cannot be simply translated into English as *Their car three and *The party at seven without the presence of appropriate to be as the main part of the predicates.

\section{Conclusion}

Most of the kinds of Indonesian predicates discussed in this article are realized differently in English sentences. As the result shows, only verbs can take the position as predicates in English. In addition to verbs in contrary, other word classes, such as nouns and adjectives, are used as predicates in Indonesian sentences. This has to be underlined to avoid grammatical mistakes when changing sentences from one language into another.

\section{References}

Aarts, Bas. 2001. English Syntax and Argumentation. New York: Palgrave MacMillan.

Aikhenvald, Alexandra Y. and R.M.W. Dixon. 2007. Grammars in Contact: A Cross-Linguistic Typology. Oxford: Oxford University Press.

Arief, M. Fathoni. 2007. Darah Jawa. Accessed on November 2013 at http://fathoniarief.blogspot.com/2007/08/darah-jawa.html.

Borsley, Robert D. 2003. Syntactic Theory: A Unified Approach. London: Arnold. 
Deterding, David H. and Gloria R. Poedjosoedarmo. 2001. The Grammar of English. Singapore: Prentice Hall.

Dickens, Charles. 2013. The Seven Poor Travelers. South Australia: The University of Adelaide.

Greenbaum, Sydney and Nelson Gerald. 2002. An Introduction to English Grammar. Great Britain: Pearson Education Limited.

Kothari, C.R. 2004. Research Methodology: Methods and Techniques. New Delhi: New Age International Publishers.

Liamputtong, Pranee. 2008. Doing Cross-Cultural Research: Ethical and Methodological Research. Melbourne: Springer.

Shopen, Timothy. 2007. Language Typology and Syntactic Description. Cambridge: Cambridge University Press.

Sneddon, James Neil. 1996. Indonesian: A Comprehensive Grammar. London: Routledge.

Sneddon, James Neil. 2000. Indonesian Reference Grammar. Melbourne: University of Sydney.

Stake, Robert E. 2010. Qualitative Research: Studying How Things Work. New York: The Guilford Press. 